\title{
ANALYSIS OF FACTORS AFFECTING PEOPLE'S BEHAVIOR IN USING ELECTRONIC PAYMENT INSTRUMENTS
}

\author{
Sri Darmadi Sudibyo1) \\ Mohammad Syamsul Maarif2) \\ Anggraini Sukmawati2) \\ M. Joko Affandi2) \\ 1) Student of School of Business, Bogor Agricultural University \\ 2) Lecturer of School of Business, Bogor Agricultural University \\ e-mail: darmadisudibyosri@gmail.com
}

\begin{abstract}
ABSTRAK
Tujuan penelitian ini adalah untuk menganalisis faktor-faktor yang mempengaruhi perilaku masyarakat menggunakan Alat Pembayaran Elektronik (APE). Pengertian APE dalam penelitian ini dibatasi pada kartu debet dan kredit. Penggunaan APE di Indonesia saat ini masih menghadapi permasalahan yang kompleks. Data yang digunakan dalam penelitian ini adalah data primer dengan memberikan kuesioner kepada responden. Survei dilakukan kepada masyarakat di wilayah Jakarta, Bogor, Depok, Tangerang dan Bekasi (Jabodetabek) dengan total responden 400 orang. Pengambilan sampel dilakukan dengan teknik purposive sampling. Kriteria yang dipergunakan dalam memilih sampel penelitian adalah responden yang berusia antara 17-56 tahun mengingat usia ini adalah usia kerja produktif dan merupakan nasabah aktif pemilik akun di bank selaku pemegang kartu debet atau kartu kredit. Untuk menjawab tujuan penelitian tersebut, digunakan Structural Equation Modelling (SEM). Menurut teori perilaku yang direncanakan (the planned behavior theory), behavior dipengaruhi oleh intention, sedangkan intention dipengaruhi oleh attitude, subjektif norm, dan perceived behavioral control. Hasil analisis SEM menunjukkan bahwa behavior masyarakat dalam menggunakan APE dipengaruhi secara dominan oleh intention, sementara intention tersebut dipengaruhi oleh perceived behavioral control.
\end{abstract}

Kata kunci: APE, Behavior, Intention, Perceived Behavioral Control

\begin{abstract}
The objective of this study is to analyze the factors that influence people's behavior in using Electronic Payment Instruments (APE). In this study, the definition of APE is limited to debit and credit card. The use of APE in Indonesia is still facing complex problems. The data used in this study is primary data by giving questionnaires to respondents. The survey was conducted on communities in Jakarta, Bogor, Depok, Tangerang and Bekasi (Jabodetabek) with a total of 400 respondents. The criteria used to select the research sample are respondents aged between 17-56 years, this age is the productive age of work and an active customer who owns the account at the Bank as the holder of a debit card or credit card. To answer that objective, Structural Equation Modeling (SEM) is used in this study. Following the theory of Planned Behavior, the behavior is influenced by intention, where as intention is influenced by attitude, subjective norm, and perceived behavioral control. The result of SEM analysis shows that people's behavior in using APE is influenced by the intention, meanwhile intention is influenced by perceived behavioral control.
\end{abstract}




\section{Keywords: APE, Behavior, Intention, Perceived Behavioral Control}

To realize the means of payment that is more smoothly, safe, efficient and reliable, innovation of payment instruments continue to develop. To innovate the community, it can use the means of payment; it is necessary to conduct the process of changing the behavior of people in transacting. In line with the development of these innovations to protect the community of APE users need support device provisions. Given these provisions according to Duraj (2017) will improve transparency associated with the imposition of fees. It is becoming increasingly relevant because the use of electronic payment instruments will become a trend in the 21st century (Worthington 1995). Changes in these trends, marked by the widespread change and development of patterns of transactions from conventional patterns to be electronic in the current era. It is a step towards accelerating the realization of a cashless society which will ultimately support the digital economy. Economic Census 2016 data conducted by the Central Bureau of Statistics (BPS), e-commerce industry of Indonesia in the last ten years grew about seventeen percent with the total number of ecommerce business reached 26.2 million.

Meanwhile, in fact, the culture of Indonesian society in transactions still tend to use cash (Pohan 2013). It is in line with the opinion of MasterCard Advisors' Cashless Journey The Global Journey From Cash to Cashless (2013) regarding the evolutionary stages of non-cash usage stating that Indonesia is currently at inception stages (based on non-cash payments of total consumer payments of $31 \%$ ). Where inception stages are the earliest stages of evolutionary stage classification consisting of inception stage ( $<40 \%)$, transitioning ( $>40 \%)$, the tipping point $(>60 \%)$ and the last step is nearly cashless (> $80 \%)$.

\section{THEORY}

\section{Regulatory Basis}

Current payment instruments in Indonesia are one of the components of the payment system, regulated under various laws and regulations. According to Law Number 23 of 1999 Concerning Bank Indonesia, the payment system is a system that includes a set of rules, institutions, and mechanisms used to carry out the transfer of funds to meet an obligation arising from economic activity. As in other countries, the current retail payment instruments in Indonesia besides using cash also use non-cash payment instruments including APE. Legal provisions that are strictly related to the use of non-cash payment instruments or electronically are closely related to the transfer of funds process which regulate in a separate law, namely Law no. 3 the year 2011. Definition of Fund Transfer System is an integrated system to process the transfer of funds by using electronic means or other means following the regulations. Concerning the legal basis of evidence of electronic transactions stipulated in article 76 states that paragraph (1) Electronic information, electronic documents and/or prints in Fund Transfer activities constitute legal proof. In paragraph (2) it is stipulated that the electronic information, electronic documents and/or prints as referred to in paragraph (1) constitute an extension of the valid evidence following the applicable law of procedure. Similarly, the signature arrangement clearly defined in section 77 which states that electronic signatures in Fund Transfer activities have legitimate legal force. It assures that the transaction electronically has legal force because it has been granted legal guarantees in the Fund Transfer Act.

Furthermore, to answer the development of technology and information system that creates to various innovations, primarily related to financial technology, Bank Indonesia has issued Bank 
Indonesia Regulation No. 18/40/PBI/2016 regarding the Implementation of Payment Transaction Processing. Other than that considering issuance the regulation to meet the needs of the community, including in the field of payment system services, both regarding instruments, organizers, mechanisms, and infrastructure of processing payment. Innovation in the processing of payment transaction needs to be continued to support the creation of a smooth, safe, efficient and reliable payment system; as well as compliance with prudential principles and adequate risk management, access extension, national interest and consumer protection, and international standards and practice. This is particularly relevant concerning financial technology to meet the needs of the community, including in the field of payment system services, concerning instruments, organizers, mechanisms, and infrastructure of payment processing transactions.

Associated with APE consisting of debit cards and credit cards are regulated in Bank Indonesia Regulation Number 14/2 / PBI / 2012 concerning Amendment to Bank Indonesia Regulation Number 11/11 / PBI / 2009 concerning Card-Based Payment Instruments. The existence of the provisions of the law will provide confidence and security for the community in conducting electronic transactions. With the existence of the provisions of these laws can be a boost for the public in changing the behavior of transactions from using cash to electronically.

\section{Theoretical and Conceptual Framework}

As the title of the study "Factor Analysis Affecting Changes in Community Behavior in Using Electronic Payment Instrument" then the theory that became the basis of this research is the theory of payment systems and the theory of planned behavior. According to the Glossary of the Payment System Bank Indonesia (2017) is a system that includes a set of rules, institutions, and mechanisms, which are used to carry out the transfer of funds to meet an obligation arising from economic activity. According to Pohan (2013) payment system can be classified into two types namely substantial value and retail value. Various things that shape the behavior of people in using APE will use approach theory of planned behavior. The purpose of the planned behavior theory, among others, is to predict and understand the influence of motivational behavior that is not under the control or the individual's own will. To identify how and where the strategic direction for behavior change is and also to explain every critical aspect of some human behavior. Intentions to perform a predictable behavior of attitudes, subjective norms, and behavioral control perceptions (Ajzen, 1991). The planned behavior theory provides a framework for learning attitudes toward behavior. Based on the theory, the most crucial determinant of a person's behavior is the intention to behave. The individual's intention to display behavior is a combination of attitudes to display such behavior and subjective norms. Individual attitudes toward behavior include beliefs about a behavior, evaluation of behavioral outcomes, subjective norms, normative beliefs and motivation to obey.

Two essential motives underlying a person's tendency to conform are the desire to be liked by others and the desire to be accurate. Both motives reflect in two different types of social, normative and informational influences. Social influences are powerful and widespread but tend to enlarge in situations where they are unsure about self-assessment of what is right (Baron and Branscombe, 2014). This perception is a reflection of past individual experiences and also obstacles or hindrances to display behavior (Baron and Branscombe, 2014).

One effort to change the culture of a society made by changing the business model mechanism so that people do not have choice but to follow the rules of the game. It happens as a result of cultural influence or a mechanism that has been done by another country which then becomes a reference for change. The social process as a result of the absorption of foreign culture 
so that elements are gradually accepted and processed into their own culture (acculturation), since the fifteenth century the process of acculturation of Western Europeans began to spread to Africa, Asia, North America (Koentjaraningrat, 2014).

To change the behavior of the community can run optimally through the stages of change can use Awareness, Desire, Knowledge, Ability, and Reinforcement (ADKAR) Model. ADKAR model is building awareness of the need for a change, the desire to support and engage in change, have known how to make changes can implement with expertise and behavior and strengthen to keep the changes going (Hiatt, 2006). To accelerate the process of cultural change in transactions using APE, it needs extensive involvement in the community, payment service industry, Bank Indonesia, and government.

\section{Previous Research}

Several previous studies have become the reference of researchers in researching so that it can enrich the theory used in reviewing research conducted. To realize the cashless society demands a change in public behavior in transactions from using cash to electronically. According to Madasu (2015), the Government should be the catalyst that regulates the economy in cashless or less-cash, with electronic payment model. The move to Nigeria without cash (cashless) brings many benefits but still needs to create greater awareness to attract Nigerian citizens who do not yet have access to the banking system (Yaqub et al, 2013). According to Szmigin and Bourne (1999) in a study in which students compared the performance of electronics cash with cash concluded that electronic cash has an advantage in certain situations and that marketing should concentrate on identifying to incorporate appropriate services into card use to benefit consumers.

Worthington (1995) promotes people without cash following the implications of imposing costs on consumers for payments with plastic cards. Considering the costs for the use of paper money and coin is expensive so that need to be replaced payments electronically to be efficient. Ajzen (1991) researched various aspects of the planned behavioral theory (Ajzen, 1985, 1987) reviewed, and several issues to which the discussion has not been resolved. Intentions to perform various behaviors can be predicted with high precision of attitudes toward behavior, subjective norms, and perceptions of behavior control; and this intention, along with the perception of behavioral control, takes into account considerable variance in actual behavior. Attitudes, subjective norms, and perceived behavior control are shown to be related to behavioral, normative, and behavioral beliefs that stand out, but the exact nature of these relationships remains uncertain.

The research undertaken by Ajzen (1991) relates to various aspects of the planned behavior theory reviewed and some of the issues with which the discussion has not been resolved. Intentions to perform various behaviors can be predicted with high precision of attitudes toward behavior, subjective norms, and perceptions.

Fishbein and Ajzen (2005) techniques and strategies developed for cognitive behavioral therapy can be used for behavioral change interventions based on planned behavior theory. Furthermore, according to $\mathrm{Li} \mathrm{W}$. and Wu (2016) aspects of motivation also contribute to various aspects of behavior.

\section{METHODOLOGY \\ Types and Data Sources}

The study data used secondary data and primary data, and primary data are survey results to the community in Jakarta, Bogor, Depok, Tangerang, and Bekasi (Jabodetabek) with a total of 400 
respondents. Sampling was done using purposive sampling technique. The criteria used to select the research sample are respondents aged between 17-56 years, this age is the working age of work and is the active customer of the account owner in the Bank as the debit card or credit card holder. This study aims to analyze the factors that influence the behavior change of the community in using APE so in this study need to require the respondent must be at least once in the past month using a debit card or credit card either for transaction activity through ATM or a merchant. Surveys are done online using google form by asking for enumerator assistance in Jabodetabek area.

\section{Data Analysis Technique}

Analyze the behavior of Indonesian people in using APE using survey results through structured questionnaires which then performed quantitative analysis using Structural Equation Modeling (SEM) model. SEM approach is a statistical analysis to see the causality relationship between variables that can not be measured directly (latent variables) simultaneously. The data in this study were analyzed using Lisrel application version 8.72. This study uses SEM analysis to see the relationship between attitude variables, subjective norms, perceived behavioral control with variable intention and behavior in using APE. This analysis is intended to see which variables influence the behavior of people in conducting transactions. SEM is used not to design theory, but rather to examine and justify a model (Mattjik and Sumertajaya, 2011).

Illustration path structural equation model can be seen in Figure 1.

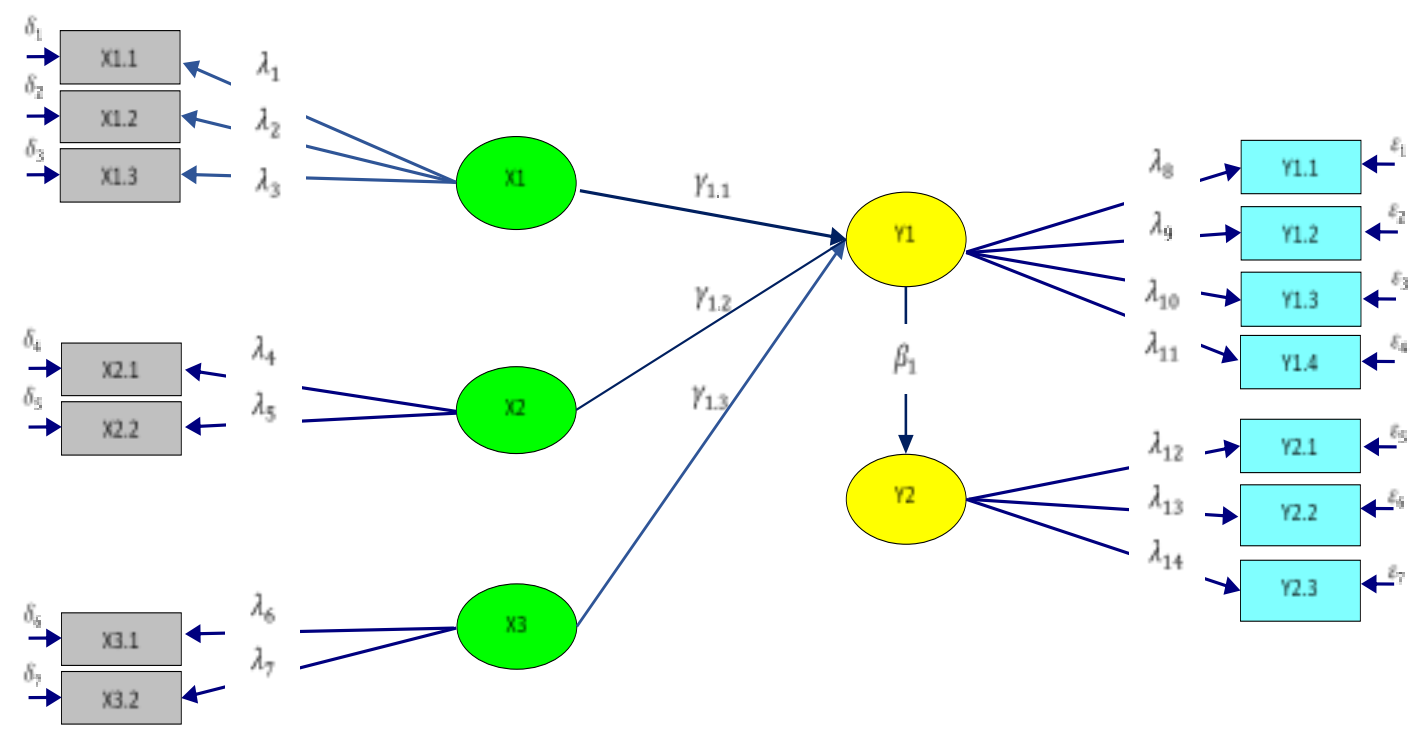

Figure 1. Illustration Path Structural Equation Model of Factors That Influence Community Behavior Using APE

\section{RESULT AND DISCUSSION}

The respondents of this study amounted to 400 people consisting of several categories namely by gender, age and income level. The description and the number of respondents involved in the study are as the following Table data 1. 
Table 1. Characteristics of Respondents by Gender

\begin{tabular}{llrllll}
\hline \multirow{3}{*}{ Gender } & \multicolumn{2}{l}{ Frekuensi $(\mathrm{n}=400)$} & & & \\
\cline { 2 - 6 } & $\begin{array}{l}\text { Jakarta } \\
(\mathrm{n}=235)\end{array}$ & $\begin{array}{c}\text { Bogor } \\
(\mathrm{n}=20)\end{array}$ & $\begin{array}{l}\text { Depok } \\
(\mathrm{n}=45)\end{array}$ & $\begin{array}{l}\text { Tangerang } \\
(\mathrm{n}=46)\end{array}$ & $\begin{array}{l}\text { Bekasi } \\
(\mathrm{n}=54)\end{array}$ & Total \\
\hline Male & 120 & 8 & 29 & 25 & 22 & 204 \\
Female & 115 & 12 & 16 & 21 & 32 & 196 \\
\hline
\end{tabular}

Table 2. Characteristics of Respondents by Age Group

\begin{tabular}{lcrrlrr}
\hline Age Category & \multicolumn{2}{l}{ Frekuensi $(\mathrm{n}=400)$} & & & \\
\cline { 2 - 6 } & $\begin{array}{l}\text { Jakarta } \\
(\mathrm{n}=235)\end{array}$ & $\begin{array}{c}\text { Bogor } \\
(\mathrm{n}=20)\end{array}$ & $\begin{array}{r}\text { Depok } \\
(\mathrm{n}=45)\end{array}$ & $\begin{array}{l}\text { Tangerang } \\
(\mathrm{n}=46)\end{array}$ & $\begin{array}{r}\text { Bekasi } \\
(\mathrm{n}=54)\end{array}$ & Total \\
\hline $17-25$ th & 57 & 3 & 10 & 12 & 7 & 89 \\
$26-35$ th & 72 & 6 & 8 & 12 & 20 & 118 \\
$36-56$ th & 106 & 11 & 27 & 22 & 27 & 193 \\
\hline
\end{tabular}

Table 3. Characteristics of Respondents by Level of Income

\begin{tabular}{|c|c|c|c|c|c|c|}
\hline \multirow[b]{2}{*}{ Income Category } & \multicolumn{5}{|c|}{ Frekuensi $(n=400)$} & \multirow[b]{2}{*}{ Total } \\
\hline & $\begin{array}{l}\text { Jakarta } \\
(n=235)\end{array}$ & $\begin{array}{l}\text { Bogor } \\
(n=20)\end{array}$ & $\begin{array}{l}\text { Depok } \\
(n=45)\end{array}$ & $\begin{array}{l}\text { Tangerang } \\
(\mathrm{n}=46)\end{array}$ & $\begin{array}{l}\text { Bekasi } \\
(n=54)\end{array}$ & \\
\hline$<$ Rp. 10.000 .000 & 100 & 4 & 14 & 19 & 16 & 153 \\
\hline Rp. 10.000 .000 - Rp. 20.000 .000 & 59 & 6 & 14 & 17 & 21 & 117 \\
\hline Rp. 20.000 .001 - Rp. 30.000 .000 & 29 & 7 & 4 & 5 & 5 & 50 \\
\hline Rp. 30.000 .001 - Rp. 40.000 .000 & 17 & 1 & 6 & 4 & 6 & 34 \\
\hline$>$ Rp. 40.000 .000 & 30 & 2 & 7 & 1 & 6 & 46 \\
\hline
\end{tabular}

Factors that influence people's behavior in using APE

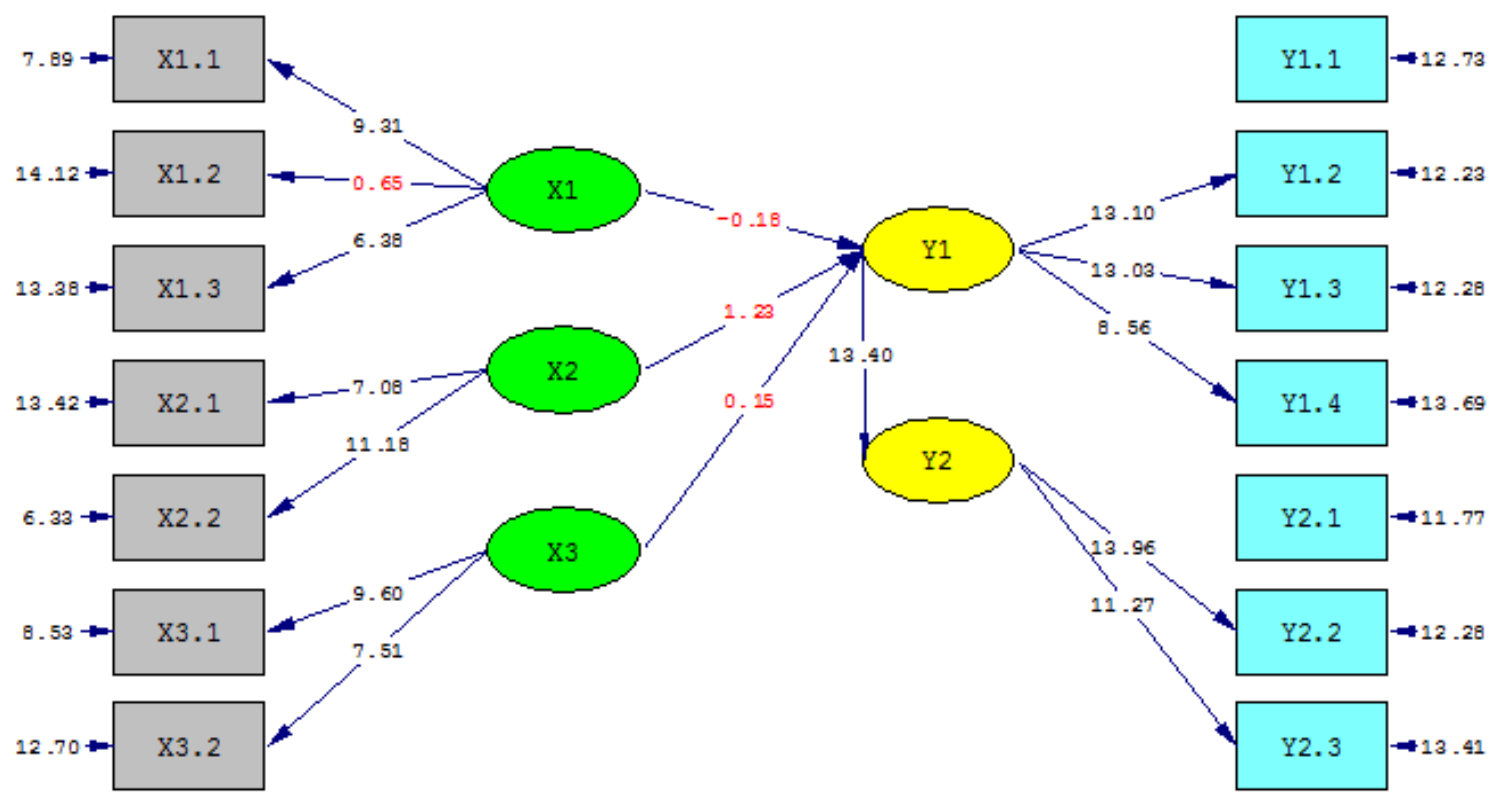

Chi-3quare $=308.28, \mathrm{df}=70, \mathrm{p}-\mathrm{value}=0.00000, \mathrm{RMSEA}=0.092$ 
Information:

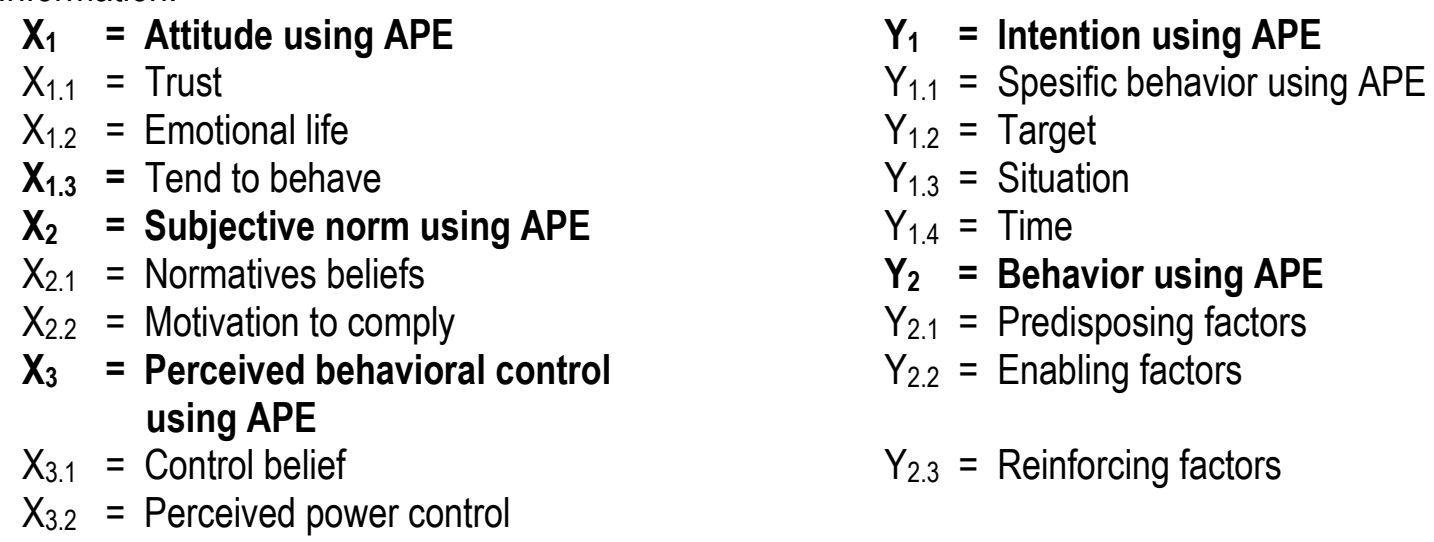

Figure 2. T-value path diagram of the initial model of factors affecting the behavioral community in using the APE Model with the result of standardized solution estimation

Figure $2 \mathrm{~T}$-value path diagram of the initial model of factors affecting the behavioral community in using the APE Model with the result of standardized solution estimation, used to know the closeness of the relationship (loading factor) which shows how strong the indicator variables reflect or measure each latent variables exogeneous attitude, subjective norm, perceived behavioral control, and latent endogeneous Intention and Behavioral. In the original hypothesis, attitude $\left(X_{1}\right)$, subjective norm $\left(X_{2}\right)$, perceived behavioral control $\left(X_{3}\right)$, and intention $\left(Y_{1}\right)$ allegedly influence behavior $\left(\mathrm{Y}_{2}\right)$ using APE. The resulting model as shown in Figure 2 declares not fit because the loading factor and possible influence are still not signed by the red color of the figure in Figure 2 (t-value $<1.96$ ), so the model must be respesification.

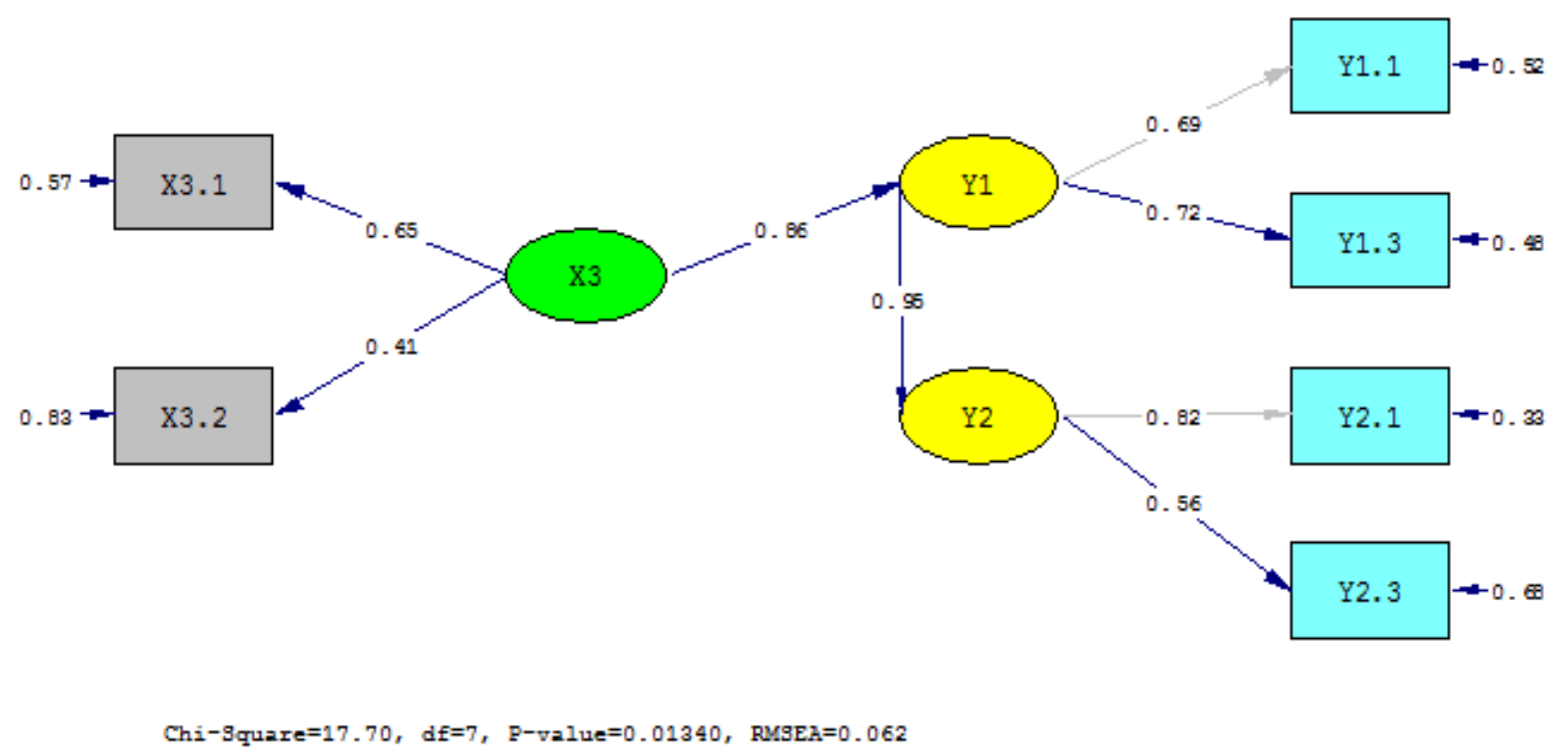


Information:

$\begin{array}{ll}X_{3}=\text { Perceived behavioral control using APE } & Y_{1}=\text { Intention using APE } \\ X_{3.1}=\text { Control belief } & Y_{1.1}=\text { Behavior } \\ X_{3}=\text { Perceived power control } & Y_{1.3}=\text { Situation } \\ & Y_{2}=\text { Behavior using APE } \\ & Y_{2.1}=\text { Predisposing factors } \\ & Y_{2.3}=\text { Reinforcing factors }\end{array}$

Figure 3. The standardized value path diagram after the respecification of a factor model affecting the behavioral community in using APE.

Figure 3 The standardized value path diagram after the respecification of a factor model affecting the behavioral community in using APE. After respecification model by issuing indicators and latent variables that are not significant. The attitude factor $\left(X_{1}\right)$, subjective norm $\left(X_{2}\right)$ does not significantly affect the intention $\left(Y_{1}\right)$ and behavioral $\left(Y_{2}\right)$, the variables are excluded from the model. Figure 3 shows the perceived behavioral control $\left(\mathrm{X}_{3}\right)$ and indirect to behavioral $\left(\mathrm{Y}_{2}\right)$ using APE.

Table 4. Absolute Measures Matching Test Results (Size of Absolute Match) and Incorrect Fit Measures Match Test Results (Incremental Match Size) Model

\begin{tabular}{|c|c|c|c|}
\hline Goodness of Fit & Cut Off Value & Estimated Results & Information \\
\hline \multicolumn{4}{|l|}{ Absolute Measures } \\
\hline Root Mean Square Error of & RMSEA $\leq 0,05=$ close fit & & \\
\hline Approximation (RMSEA) & $\begin{array}{l}0,05<\text { RMSEA } \leq 0,08 \\
=\text { good fit } 0,08<\text { RMSEA } \leq 0,10 \\
=\text { marginal fit RMSEA }>0,10=\text { poor fit }\end{array}$ & 0,062 & Good fit \\
\hline Goodness of Fit Index (GFI) & $\begin{array}{l}\mathrm{GFI} \geq 0,90=\text { good fit } 0,80 \leq \mathrm{GFI}<0,90 \\
=\text { marginal fit } \mathrm{GFI}<0,80=\text { poor fit }\end{array}$ & 0,99 & Good fit \\
\hline \multicolumn{4}{|l|}{ Incremental Fit Measures } \\
\hline Ajusted Goodness of Fit Index & AGFI $\geq 0.90=$ good fit $0,80 \leq A G F I<$ & & \\
\hline (AGFI) & $\begin{array}{l}0,90=\text { marginal fit } A G F I<0,80=\text { poor } \\
\text { fit }\end{array}$ & 0,96 & Good fit \\
\hline Normed Fit Index (NFI) & $\begin{array}{l}\mathrm{NFI} \geq 0,90=\text { good fit } 0,80 \leq \mathrm{NFI}<0,90 \\
=\text { marginal fit } \mathrm{NFI}<0,80=\text { poor fit }\end{array}$ & 0,98 & Good fit \\
\hline Tucker-Lewis Index atau Non- & $\mathrm{NNFI} \geq 0,90=$ good fit $0,80 \leq \mathrm{NNFI}<$ & & \\
\hline $\begin{array}{l}\text { Normed Fit Index (TLI atau } \\
\text { NNFI) }\end{array}$ & $\begin{array}{l}0,90=\text { marginal fit NNFI }<0,80=\text { poor } \\
\text { fit }\end{array}$ & 0,98 & Good fit \\
\hline Comparative Fit Index (CFI) & $\begin{array}{l}\mathrm{CFI} \geq 0,90=\text { good fit } 0,80 \leq \mathrm{CFI}<0,90 \\
=\text { marginal fit } \mathrm{CFI}<0,80=\text { poor fit }\end{array}$ & 0,99 & Good fit \\
\hline Incremental Fit Index (IFI) & $\begin{array}{l}|F| \geq 0,90=\text { good fit } 0,80 \leq|F|<0,90 \\
=\text { marginal fit }|F|<0,80=\text { poor fit }\end{array}$ & 0,99 & Good fit \\
\hline Relative Fit Index (RFI) & $\begin{array}{l}\mathrm{RFI} \geq 0,90=\text { good fit } 0,80 \leq \mathrm{RFI}<0,90 \\
=\text { marginal fit } \mathrm{RFI}<0,80=\text { poor fit }\end{array}$ & 0,96 & Good fit \\
\hline
\end{tabular}

Parsimonious fit measures were measured using a normed chi-square degree of compatibility. Normed chi-square is the ratio between chi-square divided by degree of freedom (df). The suggested value is lower limit $=1.0$ and upper limit $=3.0$, to see the suitability of the model with the data (good fit). The value of chi-square model $=17.70$ with the value of $d f=7$ then the ratio 
becomes 2.53, the ratio value is between the lower limit $=1.0$ and the upper limit $=3.0$. So for Parsimonious Fit Measures (size fit parsimony) model is following the data (good fit).

In conclusion, the model is good in describing the empirical data because of the three matching tests of absolute actions, absolute fit measures, incremental fit measures and parsimonious fit measures are all categorized as fit. Based on the model estimation, the coefficient value of the indicator with its latent variables and latent variables obtain. These relationships are interpreted to show the closeness or strength of relationships in both the measurement model and the structural model.

Table 5. Values of loading factors between indicator variables against exogenous and endogenous latent variables

\begin{tabular}{lll}
\hline Laten Variables & Indicator Variables & Loading Factors $(\lambda)$ \\
\hline Perceived behavioral control $\left(\mathrm{X}_{3}\right)$ & $\mathrm{X}_{3.1}$ & 0,65 \\
& $\mathrm{X}_{3.2}$ & 0,41 \\
Intention $\left(\mathrm{Y}_{1}\right)$ & $\mathrm{Y}_{1.1}$ & 0,69 \\
& $\mathrm{Y}_{1.3}$ & 0,72 \\
Behavior $\left(\mathrm{Y}_{2}\right)$ & $\mathrm{Y}_{2.1}$ & 0,82 \\
& $\mathrm{Y}_{2.3}$ & 0,56 \\
\hline
\end{tabular}

The latent variable Perceived behavioral control $\left(X_{3}\right)$ is measured by two indicators: Control belief $\left(X_{3.1}\right)$ and Perceived power control $\left(X_{3.2}\right)$. As shown in Table 5, the value loading factor control belief $\left(X_{3.1}\right)$ is 0.65 is the largest loading factor measuring the latent Perceived behavioral control $\left(X_{3}\right)$ using APE. Four indicators measure the latent Intention $\left(Y_{1}\right)$ variables: behavior $\left(Y_{1.1}\right)$, target $\left(Y_{1.2}\right)$, Situation $\left(Y_{1.3}\right)$, and Time $\left(Y_{1.4}\right)$. After the model respecification, not all real indicator variables measure the latent Intention $\left(Y_{1}\right)$. The situation indicator $\left(Y_{1.3}\right)$ is 0.72 is the largest loading factor value measuring the latent Intention $\left(Y_{1}\right)$ variable using the APE. The latent behavioral variable $\left(Y_{2}\right)$ measure by three predisposing factors $\left(Y_{2.1}\right)$, enabling factors $\left(Y_{2.2}\right)$, and reinforcing factors $\left(Y_{2.3}\right)$. After the model respecification, not all real indicator variables measure the latent variables behavior $\left(\mathrm{Y}_{2}\right)$. The predisposing factor $\left(\mathrm{Y}_{2.1}\right)$ indicator is 0.82 is the largest loading factor value measuring the latent behavioral variable $\left(\mathrm{Y}_{2}\right)$ using APE.

Table 6. Decomposition of influence between variables affecting the behaviour community in using APE

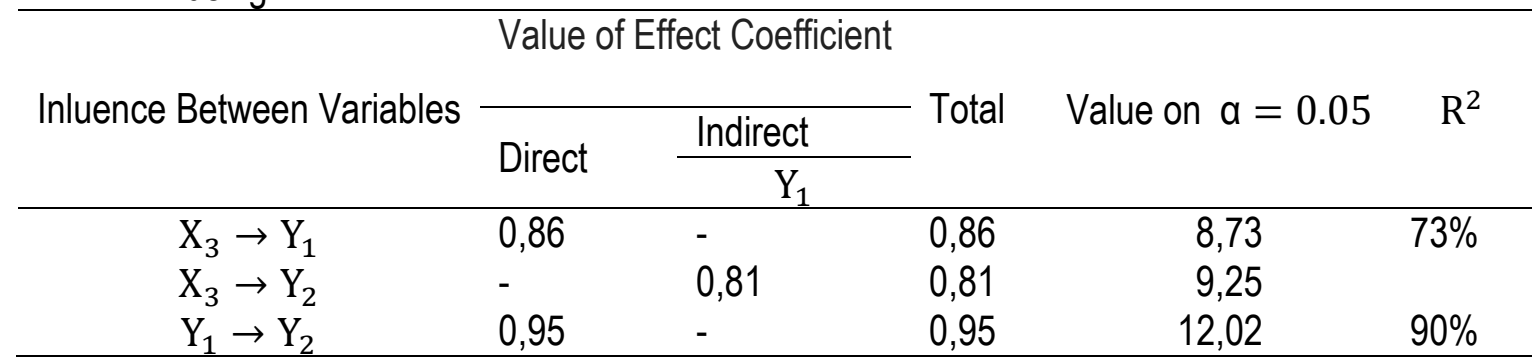

Based on the value of gamma $(\mathrm{Y})$ and beta $(\beta)$ in Table 6 it is seen that Intention $\left(Y_{1}\right)$ is influenced by perceived behavioral control $\left(X_{3}\right)$ using APE of 0,86 . The latent behavioral variable $\left(Y_{2}\right)$ 
is directly affected by the intention $\left(Y_{1}\right)$ of 0,95 and not by the perceived behavioral control $\left(X_{3}\right)$ of 0,81 . follows:

Model estimation of regression equation of factors influencing intention using API is as

$$
\widehat{\square}_{1}=0.86 \square_{3} \text { with } \square^{2}=73 \%
$$

The regression equation estimation model shows that intention using APE influence by perceived behavioral control $\left(X_{3}\right)$ factor of 0,86 with a data diversity that can be explained by 73 percent, while the rest is explained by other variables not yet contained in the model.

Community intent using APE related is the specific behavior intention on purchase/payment and supportive situation. As for perceived behavioral controls are the trust and strength of feelings to the supporting factors and inhibitors.

Model estimation of regression equation of factor affecting behavior $\left(\mathrm{Y}_{2}\right)$ using APE is as follows:

$\widehat{\square}_{2}=0.95 \square_{1}$ with $\square^{2}=90 \%$

Community behavior using APE is affected by intentions of 0.95 with $\mathrm{R}^{2} 90 \%$. Behavior associated with the model is a predisposing and reinforcing factor, whereas its intention is specific behavior intentions on purchases/payments and favorable situation.

The reasons people are still unwilling or able to switch completely using APE in the payment process are (1) Lack of confidence with the security aspects of APE, (2) Cash payment, no minimum transaction limit, and free transaction fee. Due to the small nominal payment $(<R p 50.000,-)$, people still choose to make payment transactions with cash. (3) Infrastructure is still inadequate, availability of insufficient EDC machine and supporting facilities such as internet network interruption or unreachable internet network. (4) Not all banks provide facilities and cooperation for PDAM and telephone bills payment.

As many as 294 out of 400 (73.5\%) people prefer educational methods to all communities, merchants, payment system service industries (credit cards and debit cards) so that the process of behavior change in APE realize more effectively. The community considers that if the education is done well, then the information obtained by the public is guaranteed the truth. Currently, many people in both the city and the regions do not know the advantages of making payment transactions using APE from the aspect of ease, speed, and security. Hopefully, once people understand and understand about the benefits of using APE, people will consciously switch from cash to cashless transactions. However, the availability of supporting facilities and infrastructures must also be prepared first, both regarding the existence and adequacy of EDC machines, individual readiness, and MOU cooperation.

\section{CONCLUSION}

Based on the description in the result and discussion section, it can be concluded that people's behavior in using electronic payment instruments is affected by intention, hereinafter intention is affected by perceived behavior control. Based on the conclusion as outlined, to accelerate the process of changing people's behavior from transaction in cash to electronics, it can be suggested that there is need for involvement of the community, payment service industry, Bank Indonesia and the government. Another breakthrough so that the behavior of the community in transacting experiences changes from using cash to APE optimally, can also be done through 
literacy. The substance of education must convey the message that the use of APE is safe, comfortable and smooth.

\section{REFERENCES}

Ajzen, I. (1991). The Theory of Planned Behavior. Organizational Behavior and Human Decision Processes, 50, 179-211.

Bank Indonesia. (2017). Glossary of the Payment System Bank Indonesia.

Badan Pusat Statistik. (2016). Data Sensus Ekonomi 2016.

Baron R.A, \& Branscombe N.R. (2014). Social Psychology. Harlow. Pearson

Duraj, Justyna C. (2017). The Evolution of Payment Instruments. Downloaded at http://www.worldscientificnews.com. March, 3, 2018.

Fishbein M. \& Ajzen I. (2005). Theory-based Behavior Change Interventions: Comments on Hobbis and Sutton. Journal of Health Psychology. London, Thousand Oaks and New Delhi. SAGE Publications.

Koentjaraningrat. (2014). Pengantar Antropologi. Rineka Cipta. Jakarta.

Li W. \& Wu Y. (2016). Adolescents' Social Reading: Motivation, Behaviour, and Their Relationship. Downloaded at https://doi.org/10.1108/EL-12-2015-0239.

Madasu P. (2015). India's Progress Towards Cashless Economy-An Assessment. Gavesana Journal of Management, 7 (2), 34-43.

MasterCard Advisors' Cashless Journey The Global Journey From Cash to Cashless, (2013).

Mattjik A.A, \& Sumertajaya I.M. (2011). Sidik Peubah Ganda. Departemen Statistik. FMIPA-IPB, Bogor.

Pemerintah Republik Indonesia. (1999). Undang-Undang Nomor 23 Tahun 1999 Tentang Bank Indonesia. Sekretariat Negara. Jakarta.

Pemerintah Republik Indonesia. (2011). Undang-undang Nomor 3 Tahun 2011 Tentang Transfer Dana.Sekretariat Negara. Jakarta.

Pemerintah Republik Indonesia. (2011). Undang-undang Nomor 7 Tahun 2011 Tentang Mata Uang. Sekretariat Negara. Jakarta.

Pemerintah Republik Indonesia. (2012). Peraturan Bank Indonesia Nomor 14/2/PBI/2012 Tentang Perubahan Atas Peraturan Bank Indonesia Nomor 11/11/PBI/2009 Tentang Alat Pembayaran dengan Menggunakan Kartu . Bank Indonesia. Jakarta.

Pemerintah Republik Indonesia. (2012). Peraturan Bank Indonesia Nomor 14/7/PBI/2012 Tentang Pengelolaan Uang Rupiah. Bank Indonesia. Jakarta.

Pemerintah Republik Indonesia. (2014). Peraturan Bank Indonesia Nomor 16/8/PBI/2014 Tentang Perubahan atas Peraturan Bank Indonesia Nomor 11/12/PBI/2009 Tentang Uang Elektronik. Bank Indonesia. Jakarta.

Pemerintah Republik Indonesia. (2015). Peraturan Bank Indonesia Nomor 17/3/PBI/2015 Tentang Kewajiban Penggunaan Rupiah di Wilayah Negara Kesatuan Republik Indonesia. Bank Indonesia. Jakarta.

Pemerintah Republik Indonesia. (2016). Peraturan Bank Indonesia Nomor 18/40/PBI/2016 Tentang Penyelenggaraan Pemrosesan Transaksi Pembayaran. Bank Indonesia. Jakarta.

Pemerintah Republik Indonesia. (2016). Peraturan Bank Indonesia Nomor 18/41/PBI/2016 Tentang Bilyet Giro. Bank Indonesia. Jakarta. 
Pohan A. (2013). Sistem Pembayaran Strategi dan Implementasi di Indonesia. Raja Grafindo Persada. Jakarta.

Worthington S. (1995). Cashless Society. International Journal of retail \& Distribution Management, 23(7),31-40.

Yaqub J. O, Bello H. T, Adenuga I. A. \& Ogundeji M. O. (2013). The Cashless Policy in Nigeria: Prospects and Challenges. International Journal of Humanities and Social Science, 3 (3), 200-211. 